\title{
SAFEST LEVEL OF TRICAINE METHANESULFONATE (MS- 222) TO INDUCE ANESTHESIA IN JUVENILES OF MATRINXÃ, Brycon cephalus.
}

\author{
Rodrigo ROUBACH ${ }^{1}$, Levy de Carvalho GOMES ${ }^{2}$ and Adalberto Luís VAL ${ }^{3}$.
}

\begin{abstract}
The use of MS-222 as an anesthetic for matrinxã juveniles was investigated. At dosage of $100 \mathrm{mg} / \mathrm{L}$ or lower fish did not achieve a complete anesthesia state. At $150 \mathrm{mg} / \mathrm{L}$, MS-222 induced anesthesia within 36 seconds and recovered from a 10 minutes period of anesthesia within $5.2 \mathrm{~min}$. Higher concentrations $(200,250$ and $300 \mathrm{mg} / \mathrm{L})$ anesthetized fish in lesser times, with the offset of mortality (16.7 and $33.3 \%$ ) at the 200 and $300 \mathrm{mg} / \mathrm{L} \mathrm{MS}-222$ doses, respectively. The only significant differences observed in the hematological parameters, was for the glucose values in fish anesthetized with 250 and $300 \mathrm{mg} / \mathrm{L}$. From the results, the recommended dose of MS-222 for handling matrinxã juveniles is $150 \mathrm{mg} / \mathrm{L}$.
\end{abstract}

Key-words: Brycon, matrinxã, anesthesia, MS-222, aquaculture.

Dosagem Apropriada de Tricaína Metanosulfonada (MS-222) para a Indução de Anestesia em Juvenis de Matrinxã, Brycon cephalus.

RESUMO - Investigou-se o uso de MS-222 como anestésico para juvenis de matrinxã. Concentrações de $100 \mathrm{mg} / \mathrm{L}$ ou menores não causam uma indução completa à anestesia. A 150 $\mathrm{mg} / \mathrm{L}$ os peixes foram induzidos à anestesia após 36 segundos e se recuperam em 5,2 minutos após exposição ao anestésico durante 10 minutos. Em concentrações maiores $(200,250$ e 300 $\mathrm{mg} / \mathrm{L}$ ) os peixes foram induzidos a anestesia em menor tempo, porém observou-se mortalidade de 16,7 e $33,3 \%$ nas doses de 200 e $300 \mathrm{mg} / \mathrm{L}$, respectivamente. Nos parâmetros hematológicos observou-se uma alteração significante nos niveis de glicose para os peixes anestesiados com doses de 250 e $300 \mathrm{mg} / \mathrm{L}$. Os resultados obtidos indicam que $150 \mathrm{mg} / \mathrm{L}$ é a dose ideal de MS222 para anestesiar juvenis de matrinxã.

Palavras-chave: Brycon, matrinxã, anestesia, MS-222, aqüicultura.

In research and in several handling procedures on fish farms, the use of anesthetics is essential (Ross \& Ross, 1999). For the correct usage of an anesthetic, it is important to establish its ideal dose, since unappropriated dosages can lead to undesired effects and also an eventual fish mortality (Shepherd \& Bromage, 1992). The ideal dosage is also important from an economic point of view since anesthetics are expensive and inadequate dos- ages might induce unnecessary economic losses.

MS-222 is one of the most widely used anesthetic in fish and its ideal dose has been established for several species (Ross \& Ross, 1999). It is also one of the few approved by the U.S. Food and Drug Administration for use in food fish. The effect of MS-222 on tropical fish, however, is unknown. Matrinxã, Brycon cephalus, is a tropical fish species widely used

\footnotetext{
'INPA/CPAQ, C.P. 478, Manaus, AM, Brazil, 69011-970, E-mail: roubach@inpa.gov.br ${ }^{2}$ INPA/BADPI, C.P. 478, Manaus, AM, Brazil, 69011-970, E-mail: levy@inpa.gov.br ${ }^{3}$ INPA/COPE, C.P. 478, Manaus, AM, Brazil, 69011-970, E-mail: dalval@inpa.gov.br
} 
in several rearing aquaculture systems throughout Brazil (Saint-Paul, 1986; Gomes et al., 2000) and till the moment it has is not been established the ideal dose of any kind of anesthetic drug for these fish species. The experiment was designed to estimate the ideal dose of MS-222 for juvenile matrinxã through the observation of behavioral events and metabolic and hematological stress.

Matrinxã juveniles (average weight $31.56 \pm 8.08 \mathrm{~g}$ ) were obtained from the INPA Fish Culture Station (Manaus, Amazonas, Brazil). Fish were brought from an earthen pond and placed in an indoor $2000 \mathrm{~L}$ tank for two weeks. The fish were fed once daily until satiety with a commercial pelleted feed and unfed during 24 hours prior to the trials. Experiments were conducted in a static $12 \mathrm{~L}$ aquarium containing $3 \mathrm{~L}$ of water. In all experiments MS-222 was added directly to the water before addition of the fishes. Water was replaced following each experiment. Water, after the addition of calcium carbonate, exhibited a $\mathrm{pH} 6.3$, and temperature of $25^{\circ} \mathrm{C}$.

Fishes ( $\mathrm{n}=6$ for each dosage) were individually exposed to dosages from $75,100,150,200,250$, to 300 $\mathrm{mg} / \mathrm{L}$ MS-222 for a period of ten minutes (Waterstrat, 1999), mean while behavioral responses have been observed. After that fish were removed from the MS-222 and placed in $25 \mathrm{~L}$ aquarium containing $15 \mathrm{~L}$ of aerated fresh water to observe the recovery. Immediately after recovery, blood samples were taken from the fish cau- dal vein with heparinized syringe and hematocrit and glucose levels were determined. As a control treatment for blood parameters, blood were also taken from six non-anesthetized fish from the same experimental fish batch. Evaluation of the stages of anesthesia and recovery were developed from criteria outlined in Stoskopf (1993). Differences among MS-222 concentrations in the time to achieve the respective anesthetic stages were examined using analysis of variance and Tukey test. Hematocrit and glucose levels were compared to control by analysis of variance and Dunnett's test. The analysis procedures used the Jandel SigmaStat statistical analysis software (version 2.0, 1995, Jandel Corporation) and were made at a confidence level of 0.05 .

Fish exposed to dosages of 100 $\mathrm{mg} / \mathrm{L}$ or lower did not achieve a complete anesthesia state after $10 \mathrm{~min}$ exposure period. At $150 \mathrm{mg} / \mathrm{L}, \mathrm{MS}-222$ induced anesthesia within 36 seconds and the time to reach a complete anesthesia state $(5.62 \pm 0.53 \mathrm{~min})$ was significantly different $(\mathrm{P}<0.05)$ from the other dosages (200, 250 and 300 $\mathrm{mg} / \mathrm{L}$ ) and the recovery time was 5.19 $\pm 3.07 \mathrm{~min}$. (Table 1). Fish mortality were observed during recovery for the dosages at $200 \mathrm{mg} / \mathrm{L}(16.7 \%)$ and 300 $\mathrm{mg} / \mathrm{L}(33.3 \%)$. The baseline (control treatment) values for the hematological parameters are in accordance with measurements for tropical fishes (Monteiro et al., 1987; Marcon et al., 1999). However, the control fish presented lower hematocrit values when compared to fish submitted to anesthe- 
sia, but the values were not significantly different $(p>0.454)$ (Table 2). These data contrasts with the values reported by Reinitz \& Rix (1977) and MacAvoy \& Zaepfel (1997), even though the fish hematocrit values are in the expected range when compared to other warmwater and even coldwater species (24-49\%) (Wedemeyer, 1996; Davidson et al., 2000). As for the glucose values, only at the highest doses (250 and 300 $\mathrm{mg} / \mathrm{L})$ they were significantly $(\mathrm{p}<$ 0.001 ) different from the control, showing a pronounced metabolic stress response, which is an indicator that the fish at these higher MS-222 concentrations were under some stress (Wedemeyer, 1996).

The establishment of a safe and appropriate anesthetic dosage for a tropical fish it is important under an economic perspective, since most commercial anesthetics, as the case with MS-222, are quite expensive. The concentration $(150 \mathrm{mg} / \mathrm{L})$ which in- duced matrinxã into a full anesthetic state is similar to values recommended for Tilapia sp. (100-200 mg/L), and higher than concentrations for some reported temperate species $(50-100 \mathrm{mg} / \mathrm{L})$ (reviewed by Ross \& Ross, 1999). Therefore this work may point out future recommendations to other tropical, and mainly others Amazonian species. According to Waterstrat (1999) $10 \mathrm{~min}$ is a standard time used to anesthetize fish, therefore, our study did not address the long-term consequences resulting from exposures to different dosages of the MS-222. Further studies are needed to determine the possible delayed or long-term effects.

The appropriate and safest dose of MS-222 for matrinxã juveniles is $150 \mathrm{mg} / \mathrm{L}$. This dosage has induced the fish through all stages of anesthesia, and did not cause any mortality, or stress to the animals and presented a good safety margin.

Table 1. Behavioral events of matrinxã juveniles exposed to various concentrations of MS- 222 . Values represent mean time \pm SD in minutes to the behavioral event. Stages of anesthesia are based on criteria of Stoskopf (1993): I/1 - slight loss of reactivity to visual and tactile stimuli; II/1 - loss of equilibrium; II/2 - total loss of equilibrium; III/1 - reduced opercular movement, III/2 - Minimal opercular movement; Recovery - recovery of equilibrium and swimming actively. Conc. $=$ Concentration

\begin{tabular}{|c|c|c|c|c|c|c|}
\hline \multirow[b]{2}{*}{ Conc. (mg/L) } & \multicolumn{5}{|c|}{ Behavioral event } & \multirow[b]{2}{*}{ Recovery } \\
\hline & Stage $1 / 1$ & Stage $11 / 1$ & Stage $1 / 2$ & Stage $11 / 1$ & Stage $111 / 2$ & \\
\hline 75 & $1.19 \pm 0.57^{4}$ & $4.02 \pm 1.53^{\mathrm{a}}$ & $5.87 \pm 1.80^{\mathrm{a}}$ & $10.0 \pm 0.00^{a 1}$ & $10.0 \pm 0.0^{21}$ & $2.84 \pm 0.34^{\mathrm{a}}$ \\
\hline 100 & $0.63 \pm 0.45^{b}$ & $1.54 \pm 0.41^{b}$ & $2.93 \pm 0.57^{\circ}$ & $8.81 \pm 0.78^{b}$ & $10.0 \pm 0.00^{51}$ & $3.19 \pm 0.45^{\text {ab }}$ \\
\hline 150 & $0.36 \pm 0.14^{\circ}$ & $1.23 \pm 0.60^{\circ}$ & $1.87 \pm 0.68^{\circ}$ & $4.73 \pm 0.86^{c}$ & $5.62 \pm 0.53^{b}$ & $5.19 \pm 3.07^{\mathrm{ab}}$ \\
\hline 200 & $0.32 \pm 0.10^{4}$ & $0.78 \pm 0.30^{\circ}$ & $1,16 \pm 0.10^{c}$ & $1.64 \pm 0.39^{\circ}$ & $3.94 \pm 0.57^{c}$ & $5.56 \pm 0.90^{a b}$ \\
\hline 250 & $0.19 \pm 0.05^{\circ}$ & $0.40 \pm 0.10^{\circ}$ & $0.97 \pm 0.21^{c}$ & $2.26 \pm 0.12^{d}$ & $2.63 \pm 0.33^{\circ}$ & $5.41 \pm 1.06^{\mathrm{ab}}$ \\
\hline 300 & $0.21 \pm 0.03^{\circ}$ & $0.33 \pm 0.05^{\circ}$ & $0.79 \pm 0.31^{c}$ & $2.01 \pm 0.36^{\circ}$ & $2.27 \pm 0.16^{d}$ & $6.27 \pm 1.46^{\circ}$ \\
\hline
\end{tabular}

Means within a column followed by different letters are significantly different using the Tukey test $(P<0.05)$.

'No reduction or loss of opercular movement was noted during exposition 
Table 2. Hematocrit and glucose levels of matrinxã juveniles exposed to various concentrations of MS-222. Values represent mean \pm SD. Control group consisted of six non-anesthetized fish from the same batch.

\begin{tabular}{ccc}
\hline $\begin{array}{c}\text { Concentration } \\
(\mathrm{mg} / \mathrm{L})\end{array}$ & $\begin{array}{c}\text { Hematocrit } \\
(\%)\end{array}$ & $\begin{array}{c}\text { Glucose } \\
(\mathrm{mg} / \mathrm{dl})\end{array}$ \\
\hline Control & $29.33 \pm 3.01$ & $90.45 \pm 20.21$ \\
75 & $36.17 \pm 6.43$ & $86.32 \pm 16.88$ \\
100 & $30.40 \pm 7.09$ & $112.32 \pm 20.21$ \\
150 & $34.00 \pm 4.90$ & $128.22 \pm 47.45$ \\
200 & $32.00 \pm 3.08$ & $130.22 \pm 7.62$ \\
250 & $32.83 \pm 6.80$ & $187.44 \pm 54.41^{*}$ \\
300 & $33.25 \pm 5.91$ & $177.57 \pm 64.60^{*}$ \\
\hline
\end{tabular}

Means within a column followed by * are significantly different from the control using the Dunnett's test $(P<0.05)$.

\section{ACKNOWLEDGIMENTS}

The authors thank J.I. Fim from the Aquaculture Department/INPA for the donated fish and the student staff at LEEM/INPA for their technical assistance during the work. This work was partially supported by $\mathrm{CNPq}$ and MCT/INPA.

\section{Literature cited}

Davidson, G.W.; Davie, P.S.; Young, G.; Fowler, R.T. 2000. Physiological responses of rainbow trout Oncorhynchus mykiss to crowding and anesthesia with AQUI-S. Journal of the World Aquaculture Society, 31(1): 105-114.

Gomes, L.C.; Baldisserotto, B.; Senhorini, J.A. 2000, Effect of stocking density on water quality, survival and growth of larvae of matrinxã Brycon cephalus (Characidae) in ponds. Aquaculture, 183: 73-81.

MacAvoy, S.E.; Zaepfel, R.C. 1997. Effects of tricaine methanesulfonate (MS-222) on hematocrit: first field measurements on blacknose dace. Transactions of the American Fisheries Society, 126: 500-503.

Marcon, J.L.; Chagas, E.C.; Kavassaki, J.M.; Val, A.L. 1999. Intraerytrocytic phosphates in 25 species of the Amazon: GTP as a key factor in the regulation of $\mathrm{Hb}-\mathrm{O} 2$ affinity. In: A.L. Val \& V.M.F. AlmeidaVal (Ed.), Biology of Tropical Fishes. Instituto Nacional de Pesquisas da Amazônia (INPA), Manaus, Amazonas, p. 229-240.

Monteiro, P.J.C.; Val, A.L.; Almeida-Val, V.M.F. 1987. Biological aspects of Amazonian fishes. Hemoglobin, hematology, intraerythrocytic phosphates, and whole blood bohr effect of Mylossoma duriventris. Canadian Journal of Zoology, 65: 1805-1811.

Reinitz, G.L.; Rix, J. 1977. Effects of tricaine methanesulfonate (MS-222) on hematocrit values in rainbow trout. Comparative Biochemistry and Physiology, 56C: 115-116.

Ross, L.G.; Ross, B. 1999. Anaesthetic and sedative techniques for aquatic animals. Blackwell Science Ltd., Oxford, UK. 159 p.

Saint-Paul, U. 1986. Potential for aquaculture 
of South American freshwater fishes: a review. Aquaculture, 54: 205-240.

Shepherd, J.; Bromage, N. 1992. Intensive fish farming. Blackwell Science Ltd., Oxford, UK. 404 p.

Stoskopf, M. 1993. Anesthesia. In Brown, L. (ed.). Aquaculture for veterinarians: fish husbrandy and medicine. Pergamon Veterinary Handbook Series, London, UK. p. 161-168.

Waterstrat, P.R. 1999. Induction and recovery from anesthesia in channel catfish Ictalurus punctatus fingerlings exposed to clove oil. Journal of the World Aquaculture Society, 30(2): 250-255.

Wedemeyer, G. A. 1996. Physiology of fish in intensive culture systems. Chapman \& Hall, New York, USA. 232 p. 